\title{
Comparison of Simultaneous Shunting to Delayed Shunting in Infants with Myelomeningocele in Terms of Shunt Infection Rate
}

\author{
Şant Infeksiyon Oranı Açısından Myelomengoselli İfantlarda Aynı \\ Seansda Şantlamanın Geç Dönem Şantlamayla Karşılaştırılması
}

\author{
Mehmet ARSLAN, Metehan ESEOGLU, Burhan Oral GUDU, Ismail DEMIR, Abdulbaki KOZAN, \\ Abdulsemat GOKALP, Enver SOSUNCU, Nejmi KIYMAZ \\ Yuzuncu Yil University, Faculty of Medicine, Department of Neurosurgery, Van, Turkey
}

Correspondence address: Mehmet ARSLAN / E-mail: arslan2002@hotmail.com

\begin{abstract}
AIM: Timing of shunt insertion in infants with myelomeningocele (MM) and hydrocephalus (HCP) has been debated. Many authors have suggested to perform the repair of MM and shunt insertion during same operation. However, there is also an opposite view.

MATERIAL and METHODS: We analyzed retrospectively 166 patients who underwent MM Sac repair to evaluate whether there are difference between these two methods in terms of shunt infection rate.

RESULTS: In the same session, V-P (ventriculoperitoneal) shunt placement was performed onto 65 infants within the first 48 hours of postnatal and 36 infants were operated 48 hours after birth. In separate sessions, repair of MM were performed onto 29 infants within the first 48 hours of postnatal and shunting was peformed 7 days after sac repair. 14 infants were performed MM sac repair 48 hours after birth, then shunt was applied 7 days after closure of MM. Shunt infection rate in concurrently operated groups was markedly high ( $12.3 \%$ in early surgery, $33.3 \%$ in late surgery); in separatedly operated groups' shunt infection rate was lower (3.44\% in early surgery, $14.29 \%$ in late surgery).
\end{abstract}

CONCLUSION: We propose to perform V-P shunt placement and MM repair in separate sessions.

KEYWORDS: Hydrocephalus, Myelomeningocele, Ventriculoperitoneal shunt, Shunt infection

öz

AMAÇ: Myelomeningoselli ve hidrosefali infantlarda şant yerleştirme zamanı tartışmalıdır. Bir çok yazar myelomeningosel tamirini ve şant yerleştirmeyi aynı operasyon süresince yapmayı önerirler. Bununla birlikte, karşıt görüşlerde vardır.

YÖNTEM ve GEREÇ: Biz şant infeksiyonu oranı açısından bu iki yöntem arasında fark olup olmadığını değerlendirmek için myelomeningosel kese tamiri yapılan 166 hastayı geriye dönük olarak inceledik.

BULGULAR: Yaşamın ilk 48 saat içinde 65 infanta aynı seansda şant yerleştirilmesi ve myelomeningosel tamiri yapıldı ve doğumdan 48 saat sonra (3 ile 7 gün arasında) 36 infanta yine aynı seansda şant yerleştirilmesi ve kese tamiri yapıldı. Ayrıca yaşamın ilk 48 saat içinde 29 infanta myelomeningosel tamiri yapıldı ve ortalama 7 gün sonra ayrı bir seansda şant takıldı. 14 infanta myelomeningosel tamiri yapıldı doğumdan 48 saat sonra (doğumdan sonra 3 ile 7 gün arasında) ve kese tamirinde 7 gün sonra şant takıldı. Şant infeksiyon oranı aynı anda ameliyat edilen grupta belirgin olarak yüksekti (erken cerrahi yapılan grupta: \%12.3, Geç cerrahi yapılan grupta: \%33.3). Ayrı seanslarda ameliyat edilen grupta şant infeksiyon oranı düşüktü (erken cerrahi yapılan grupta: \%3.44, geç cerrahi yapılan grupta: \%14.29).

SONUÇ: Sonuç olarak biz ayrı seanslarda myelomeningosel kese tamiri ve şant yerleştirilmesini öneriyoruz.

ANAHTAR SÖZCÜKLER: Hidrosefali, Myelomeningosel, Ventriküloperitoneal şant, Şant infeksiyonu 


\section{INTRODUCTION}

Hydrocephalus (HCP) is commonly seen disease in association with myelomeningocele (MM) (16). HCP is seen of 65 to $93 \%$ of children with $\mathrm{MM}(10,11,15,18,20,21)$, but 5 to $10 \%$ of children with $\mathrm{MM}$ are born with hydrocephalus at birth and the majority of them will need surgical treatment for HCP. Timing of shunt insertion in infants with MM and HCP has been debated. Many authors have suggested the repair of $\mathrm{MM}$ and shunt insertion during same session $(4,10,12,20)$. According to them, in patients with HCP and MM, insertion of shunt in same session would provide a swift recovery of back, avoid a second operation, protect the brain from deterious effects of progressive HCP resulting from delayed shunting and decrease duration of hospitalization $(7,10,15$, $20,23)$. However, there is also an opposite view; concurrent shunt surgery, in same session, may cause an increased shunt infection risk, which is a common complication of shunting in the patients with MM, observed between the rates of 2-39\% (18), because ventricular shunt placement reverses cerebrospinal fluid (CSF) flow from the lumbar region to ventricles $(3,9,18)$. Therefore, shunt placement performed within a week of closure of infected myelomeningocele sac could increase the risk of shunt infection.

Most researchers suggest that repair of $\mathrm{MM}$ sac in first 24-48 hours decrease risk of infection. The repair after 48 hours of MM sac causes a significant increase in mortality and morbidity rate $(2,15,18)$. In this study, we reviewed our experience of a decade with these two methods (MM repair and shunt placement in same session and in separate sessions) to evaluate whether there are differences between these two methods in terms of shunt infection rate.

\section{MATERIAL and METHODS}

We analyzed retrospectively all patients who underwent MM sac repair and V-P shunt placement at our instution from January 2000 to January 2010. In almost a decade, 166 infants with MM were operated. All files of infants with MM who were treated at Neurosurgery Clinic of Yüzüncü Yıl University were retrospectively analyzed. Information about patients' condition, type of surgical procedure, period between repair of MM and V-P shunt placement and period between shunt insertion and onset of the infection were gathered. Risk factors predisposing to shunt infection among patients with $\mathrm{MM}$ and the long-term outcome of these patients was evaluated. The gender types were recorded (75 girls, 91 boys). The patients' ages ranged from 1 day to 15 days (average 4 days) (Table I). The decision to perform V-P shunt placement (whether concurrently or separately) was dependent on physical examination findings, increase in head circumference, fontanelle bulging, vomiting and sunset eye. The perforation and infection status of the MM sac was also evaluated. An effort was made to do the repair within the first 48 hours of postnatal (109 infant); However, for the 57 cases referred to the hospital after the first 48 hours period (between 3 and 7 days), the repair of the myelomeningocele was carried out after the first 48 hours after birth.

The cases were classified into five groups: Group I: Both sac repair and V-P shunt placement were performed in the first postnatal 48 hours during the same operation. This group consisted of 65 patients born with MM and HCP at our center. Group II: MM sac repair was performed within the first 48 postnatal hours and then a V-P shunt was inserted 7-30 days after MM repair. This group consisted of 29 patients born with myelomeningocele at our center, without overt HCP. Group II consisted of those who presented with clinical and radiological evidence of mild HCP and underwent MM repair operation and shunt placement in separate sessions. Group III consisted of 36 patients with overt hydrocephalus at the time they were admitted to our clinic. The patients underwent both shunt placement and myelomeningocele repair at the same session 48 hours after birth. These patients were born in other hospitals and operated between 3 and 7 days after birth. Group IV consisted of 14 children who did not require insertion of shunt at the time of repair of myelomeningocele (48 hours after birth), but required a second operation for shunt placement due to development of hydrocephalus after the first operation. The patients in this group were born in our hospital. Group V included children who did not require insertion of shunt and of 166 patients, 22 underwent only MM repair (between 1 day and 7 days of postnatal). These infants never needed shunt placement. All of the patients received a ventriculoperitoneal shunt were followed-up for at least 1 year, but the duration of follow-up was not equal. Group I and III consisted of those who presented with clinical and radiological evidence of severe hydrocephalus and underwent myelomeningocele repair and shunt placement concurrently. In group II and IV, their shunt were inserted at various times after initial repair of myelomeningocele (ranging 7 days to 30 days). Shunt placement was performed

Table I: Age and Sex of Infants

\begin{tabular}{|c|c|c|c|}
\hline Group & Male & Female & Age at time of repair \\
\hline Group 1 (Simultaneous Early surgery) & 38 & 27 & 24-48 hours \\
\hline Group 2 (Separate Early surgery) & 15 & 14 & 24-48 hours \\
\hline Group 3 (Simultaneous Late surgery) & 23 & 13 & 48 hours- 15 days \\
\hline Group 4 (Separate Late surgery) & 7 & 7 & 48 hours- 15 days \\
\hline Group 5 (only MM repair) & 8 & 14 & 24 hours-7 days \\
\hline
\end{tabular}


after myelomeningocele sac repair in a separate session having eliminated clinical meningitis and wound infection. In all patients with cerebrospinal fluid leakage, shunt was inserted in 7 - 30 days after the first closure of MM. An antibiotic was given 30 minutes before surgery and same antibiotic was continued for seven days in most patients. Also the shunt system was immersed into a solution of saline containing $500 \mathrm{mg}$ vancomycin. The cases were evaluated daily in terms of wound infection, cerebrospinal fluid leakage and shunt infection. The diagnosis of HCP was based on large head, split sutures a bulging fontanelle and confirmed radiologically with ultrasound and/or computed tomographic scan. Clinical findings such as fever, recurrent vomiting, poor feeding, depressed consciousness, irritability, seizure, and bulging tense anterior fontanel factors were the preliminary findings that made us think about V-P shunt infection. When we thought about infection, cerebrospinal fluid from the shunt reservoir or from ventricular tapping was obtained. The number of patients with shunt infection was determined for each group. Once infection had been confirmed, the shunt was removed and external ventricular drainage was inserted until 3 CSF successive samples became sterile and the protein content got back to normal. A new shunt was then inserted. No shunt type was changed during the period of the study. Anesthetic time was usually about 45 minutes for myelomeningocele repair, and between 70 minutes and 120 minutes for concurrent procedure, with a mean of 90 minutes. Four patients were infected already and required antibiotics, correction of the back lesion, and placement of an external ventricular drainage, but these patients were not included in the study. We compared the shunt infection rates between the groups. Comparison of proportion with the $\mathrm{Z}$ test was used for statistical analyses.

\section{RESULTS}

Of 166 patients included in the study, 109 infants underwent MM repair within the first 48 postnatal hours, and 57 infants were operated on 48 hours after birth (between 3 and 7 days). 22 patients (13.2\%) were operated only for the repair of myelomeningocele and these followed up infants had no HCP. 144 infants ( 86.7 \%) with MM had V-P shunting. At the same session, shunt placement was performed for 65 infants in group I (early surgery), and 36 infants in group III (late surgery). The repair of myelomeningocele and shunt placement in separate sessions were used for 29 infants in group II (early surgery), and 14 infants in group IV (late surgery).

Shunt infection rates were markedly higher in group III. The infection rate in this group was $33.3 \%$. Of the144 infants inserted a shunt, 23 had shunt infection (15.9\%). 8 infants (12.3\%) with infection were in group I, 12 infants (33.3\%) were in group III, 2 infants (14.2\%) were in group IV and 1 infant (3.44\%) was in the group II (Table II). Of the 23 patients with shunt infection, 20 were in the simultaneous group (19.8\%) and 3 were in the separately operated group (6.98\%). There was a significant difference between the simultaneous group and the separately operated group $(p<0.05)$. There was also a statistically significant difference between early surgery and late surgery for the total patients group and simultaneous group $\mathrm{p}<0.05$ ) (Table III). The shortest period between MM repair and shunt placement was 7 days and the longest period

Table II: Rate of Shunt Infection of Groups

\begin{tabular}{|l|c|c|c|c|c|}
\hline & $\begin{array}{c}\text { Group 1 } \\
\text { (Simultaneous Early surgery) }\end{array}$ & $\begin{array}{c}\text { Group 2 } \\
\text { (Separate } \\
\text { Early surgery) }\end{array}$ & $\begin{array}{c}\text { Group 3 } \\
\text { (Simultaneous } \\
\text { Late surgery) }\end{array}$ & $\begin{array}{c}\text { Group 4 } \\
\text { (Separate } \\
\text { Late surgery) }\end{array}$ & $\begin{array}{c}\text { Group 5 } \\
\text { (only MM repair) }\end{array}$ \\
$\begin{array}{l}\text { Number of } \\
\text { patients }\end{array}$ & 65 & 29 & 36 & 14 & 22 \\
\hline \begin{tabular}{l} 
Shunt infection \\
\hline
\end{tabular} & $8(12.3 \%)$ & $1(3.44 \%)$ & $12(33.3 \%)$ & $2(14.2 \%)$ & - \\
\hline
\end{tabular}

Table III: Types of Procedures

\begin{tabular}{|c|c|c|c|c|c|}
\hline & Type of surgery & $\begin{array}{l}\text { Number of } \\
\text { patients }\end{array}$ & $\begin{array}{l}\text { Number of } \\
\text { infection }\end{array}$ & $\begin{array}{l}\text { Rate of } \\
\text { infection }\end{array}$ & P value \\
\hline Total & $\begin{array}{ll}\text { Early surgery } & \text { (within } 48 \text { hours) } \\
\text { Late surgery } & \text { (after } 48 \text { hours) }\end{array}$ & $\begin{array}{r}109 \\
57\end{array}$ & $\begin{array}{r}9 \\
13\end{array}$ & $\begin{array}{l}8.26 \% \\
22.8 \%\end{array}$ & 0.018 \\
\hline $\begin{array}{l}\text { Simultaneous } \\
\text { session group }\end{array}$ & $\begin{array}{ll}\text { Early surgery } & \text { (within } 48 \text { hours) } \\
\text { Late surgery } & \text { (after } 48 \text { hours) }\end{array}$ & $\begin{array}{l}65 \\
36\end{array}$ & $\begin{array}{r}8 \\
12\end{array}$ & $\begin{array}{l}12.3 \% \\
33.3 \%\end{array}$ & 0.018 \\
\hline $\begin{array}{l}\text { Separate session } \\
\text { group }\end{array}$ & $\begin{array}{ll}\text { Early surgery } & \text { (within } 48 \text { hours) } \\
\text { Late surgery } & \text { (after } 48 \text { hours) }\end{array}$ & $\begin{array}{l}29 \\
14\end{array}$ & $\begin{array}{l}1 \\
2\end{array}$ & $\begin{array}{r}3.44 \% \\
14.29 \%\end{array}$ & 0.276 \\
\hline Both group & $\begin{array}{ll}\text { Simultaneous (in same session) } \\
\text { Separate } \quad \text { (in separate session) }\end{array}$ & $\begin{array}{r}101 \\
43\end{array}$ & $\begin{array}{r}20 \\
3\end{array}$ & $\begin{array}{l}19.8 \% \\
6.98 \%\end{array}$ & 0.021 \\
\hline
\end{tabular}


was 1 month. 22 infants underwent shunt surgery between 7 and 10 days, 11 infants were operated between 10 and 20 days, and 10 infants were operated between 20 and 30 days.

In our study, the relationship between shunt infection and the age of the infant was not identified because the ages of all of patients that were included in the study were under 30 days. The average time between shunt infection and insertion of shunt was 38.2 days (ranged from 12 days to 123 days) (Table IV). Delayed repair of myelomeningocele sac facilitated shunt infection in group III and IV. There was a correlation between the timing of myelomeningocele repair and shunt infection. CSF leakage caused by MM sac perforation was detected in 6 of 38 patients who were operated in separate sessions; there was CSF leakage in groups 2 and 4 after the MM sac was repaired (Table $\mathrm{V}$ ); therefore, serial ventricular taps were applied in order to decrease the increasing intracranial pressure until the VP shunt was inserted as CSF leakage may increase the risk of shunt infection. 17 patients developed wound breakdown at the area of the MM repair, but there were no shunt infections detected in these infants (Table V). 9 infants died. 4 of them within the first month of their lives. Central nervous system infection was the most common cause of death, especially because of ventriculitis. Dead ones were severely debitated. In this study, the most common cause of shunt infection was of gram negative bacteria, followed by $\mathrm{S}$. aureus and coagulase negative stapylococucs. After the diagnosis of shunt infection, the colonized shunts were removed and ventricular external drainage was applied. The empirically used antibiotics were ceftazidime and vancomycin. The average duration of intravenous antibiotic treatment was 10 days; after this period, CSF culture was seen to be negative and clinical improvement was then observed (usually between 14 and 21 days). Intraventricular antibiotics such as gentamycin or vancomycin were tried in ventriculitis for 5 days. With the infection cured, a new shunt system with peritoneal catheter was inserted. The average number of external ventricular drainage that were applied per patient who developed shunt infection was 3; and 4 was the maximum number. Each patient with shunt infection was revised 2 times for V-P shunt on average during follow-up. Most lesions were located in the lumbar area (lumbar region, 133; thoracal, 26; cervical, 5; sacral, 2) (Table VI).

Table IV: Period between Shunt Placement and Onset of Infection

\begin{tabular}{|l|c|c|c|c|} 
& $\begin{array}{c}\text { Group 1 } \\
\text { (Simultaneous } \\
\text { Early surgery) }\end{array}$ & $\begin{array}{c}\text { Group 2 } \\
\text { (Separate } \\
\text { Early surgery) }\end{array}$ & $\begin{array}{c}\text { Group 3 } \\
\text { (Simultaneous } \\
\text { Late surgery) }\end{array}$ & $\begin{array}{c}\text { Group 4 } \\
\text { (Separate } \\
\text { Late surgery) }\end{array}$ \\
\hline $\mathbf{1 2 - 3 0}$ days & 4 & & 6 & \\
\hline $\mathbf{3 0 - 6 0}$ days & 3 & 1 & 5 & \\
\hline $\mathbf{6 0 - 9 0}$ days & 1 & & 1 & \\
\hline $\mathbf{9 0 - 1 2 3}$ days & & & & \\
\hline
\end{tabular}

Table V: Number of Complications in the Groups

\begin{tabular}{l|c|c|c|c|c} 
& $\begin{array}{c}\text { Group 1 } \\
\text { (Simultaneous } \\
\text { Early surgery) }\end{array}$ & $\begin{array}{c}\text { Group 2 } \\
\text { (Separate } \\
\text { Early surgery) }\end{array}$ & $\begin{array}{c}\text { Group 3 } \\
\text { (Simultaneous } \\
\text { Late surgery) }\end{array}$ & $\begin{array}{c}\text { Group 4 } \\
\text { (Separate } \\
\text { Late surgery) }\end{array}$ & $\begin{array}{c}\text { Group 5 } \\
\text { (only MM repair) }\end{array}$ \\
\hline $\begin{array}{l}\text { Wound breakdown } \\
\text { after repair }\end{array}$ & 3 & 5 & 4 & 5 & - \\
\hline CSF fistula of MM & - & 4 & - & 2 & - \\
\hline Death & 3 & - & 6 & - & -
\end{tabular}

Table VI: Locations of Myelomeningocele

\begin{tabular}{l|c|c|c|c|c} 
Location of MM & $\begin{array}{c}\text { Group 1 } \\
\text { (Simultaneous } \\
\text { Early surgery) }\end{array}$ & $\begin{array}{c}\text { Group 2 } \\
\text { (Separate } \\
\text { Early surgery) }\end{array}$ & $\begin{array}{c}\text { Group 3 } \\
\text { (Simultaneous } \\
\text { Late surgery) }\end{array}$ & $\begin{array}{c}\text { Group 4 } \\
\text { (Separate } \\
\text { Late surgery) }\end{array}$ & $\begin{array}{c}\text { Group 5 } \\
\text { (only MM repair) }\end{array}$ \\
\hline Cervical & - & - & - & - & 5 \\
\hline Thoracal & 13 & 7 & 6 & - & - \\
\hline Lumbar & 52 & 22 & 28 & 14 & 17 \\
\hline Sacral & - & - & 2 & - & - \\
\hline
\end{tabular}




\section{DISCUSSION}

HCP is among the most commonly observed disorders with MM. Shunts that are inserted for treatment of HCP with MM are quite susceptible to bacterial infections. Shunt infection was observed around $8-11 \%$ in the patients who had been applied V-P shunt placement. $70 \%$ of them suffered the infection within the first 2 months postoperatively (13). The International Society of Pediatric Neurosurgeons (ISPN) reported a high infection rate as $23 \%$, particularly, in long term follow-up (6). The incidence of shunt infection was reported as $12 \%$ by McLone (14); $5.2 \%$ by Brau et al. (2); and $25.8 \%$ by Gamache (9). In our study, the incidence of shunt infection was reported as $15.9 \%$ in the patients with myelomeningocele. This rate was relatively similar to many other studies. In our study, pediatric shunt infection rates were the highest among patients in the first 30 postnatal days after shunt placement. However, the timing of shunt insertion to the infants with HCP together with $\mathrm{MM}$ remains controversial. There are different views and studies about timing of shunt placement to cases that are suffering from MM and HCP.

Shunt infection rates following simultaneous MM sac repair and shunt placement were reported as $25.8 \%$ by Gamache (9), $23.1 \%$ by Calderelli et al.(3), $12 \%$ by McLone (14), $7.5 \%$ by Ersahin et al (8) and $5.2 \%$ by Brau (2). In this study, shunt infection rate in concurrent procedure was reported as $12.3 \%$ in early surgery, and $33.3 \%$ in late surgery. Our shunt infection rate is observed to be higher than reported in other studies, which may be caused by the delayed repair of MM sac. In 10 patients, Hubbalah and Hoffman (10) found that simultaneous repair of MM and insertion of the V-P shunt in infant with HCP at birth is safer. They reported that V-P shunt placement in the same session with MM sac repair decreased wound problems. Epstein et al. (7) and Radmanesh et al. (20) indicated that V-P shunt placement can be performed concurrently with $\mathrm{MM}$ repair without causing more complications than in separate application. Some authors $(4,10,12,15,20)$ have indicated that simultaneous MM repair and shunt insertion in infants with overt HCP at birth is a safe method and does not increase risk of shunt complication, decreases risk of further brain damage and decreases risk of wound breakdown and CSF leakage; Machado and DeOlivera (12) concluded in their study on 24 patients with HCP that simultaneous shunt placement and $\mathrm{MM}$ repair does not pose more risk than delayed shunt placement.

Some researchers $(3,18)$ are reluctant to place shunting in same session with MM sac repair in HCP cases and they offer shunt placement after elimination of meningitis or ventriculitis. Researchers that suggest shunt placement in postoperative first week, having the infection eliminated following to MM sac repair. In study Oktem et al. (18), cases which had shunt placement in same session with MM sac repair had meningitis rate of $19.3 \%$ and patients who had shunt placement in separate sessions had a meningitis rate of $9.5 \%$. Calderelli et al. (3) reported the shunt infection rate as $23 \%$ in the cases who were placed shunt in same session with MM sac repair; and 7\% in patients inserted shunt in separate sessions. Netanyahu and Grant (17) published a series of 18 infants with MM. They found the shunt infection rate to be $20 \%$ in simultaneous group. Bell et al.(1) reported the rate of shunt infection as $6 \%$ in cases who had shunt placement in the same session with MM sac repair and they reported that no shunt infection developed when the shunt was inserted in a separate session. In our study, shunt infection rate in separate session was reported as $3.44 \%$ in early surgery and $14.29 \%$ in delayed surgery. Authors that advocate placing a shunt in a separate session have postulated that shunt insertion allows CSF to reach the ventricles from the lumbar region by reversing CSF flow, facilitating infection. Therefore the authors believe that shunts inserted within the first week of closure of MM sac increase the risk of infection, and recommend a delay from 3 to 7 days after closure of MM sac before shunt surgery $(1,17,18)$. Early reports proposed sequential treatment due to higher infective complications of simultaneous repair (23). Calderelli et al.(3) stated concurrent procedures could decrease the risk of cerebrospinal fuid leakage, but there is always risk of shunt infection.

Although some authors claim that there is no difference between early and delayed closure of MM sac $(5,22)$. Tuli et al. (23), however, in their prospective study of $189 \mathrm{HCP}$ with $\mathrm{MM}$ found out that shunt placement concurrent or following to MM repair surgery was not considered to be significant in terms of infection outcomes. Parent and McMillan (19) analyzed 69 patients and stated that delayed or simultaneous shunt placement with repair of MM did not increase risk of shunt infection significantly within the first year of birth. The author also noted that nearly $9 \%$ of patients with MM never needed shunt placement; (3). In this study, 22 of 166 patients never needed to be shunted. We do not prefer to place shunts in asymptomatic patients with stable and nonprogressive HCP and therefore we state that avoiding unnecessary shunting is advisable.

There is a controversy to be taken into account in terms of optimal timing of operation for MM sac. Brau et al. (2) stated that there is no difference between early closure and late closure of the MM sac and repair of the MM did not reduce the risk of ventriculitis before or after 48 postnatal hours. It is now clearly stated that any delay in closure increases the risk of infection. In our study, there is an evidence putting forward that MM should be repaired early because a delay increases the risk of infection and we defend early closure of MM sac. The rate of shunt infection was much higher in delayed MM repair than in early MM repair. Losing chance of early repair may lead to a higher risk of infection. The most proper MM sac closure time was reported as within 36 hours after birth (18).

For 65 patients (group 1) and 36 patients (group 3) with overt HCP at birth, simultaneous MM sac repair and ventricular shunting were carried out to decrease the risk of further brain damage because of HCP and to prevent CSF leakage.

In our study, shunt infection rates were compared in the simultaneous group and the separate group. Rate of shunt infection seen to be markedly higher in simultaneous group, especially when repair of MM sac was performed 
late. The increased rates of shunt infection in group III may resulted from operating urgently due to overt HCP. Our data showed that infants born at our institution who underwent shunt placement and MM repair at a separate session had a lower shunt infection rate. There was an average difference statistically between the simultaneous group and separate group. In our study, patients with shunt infection had usually ventriculitis. In McLone's series (14), the incidence of ventriculitis was $7 \%$ following a repair done more than 48 hours after birth.

If there are MM sac perforation and CSF leakage, we propose that shunting and sac repair in a separate session should be performed to decrease risk of shunt infection. These patients can also be treated with consecutive ventricular taps to reduce intracranial pressure. We prefer two stages of operation in order to eliminate the possibility of infection development after MM sac surgery. We do not favour to place a shunt in early period to avoid shunt infection in patients with MM who present mild HCP at birth. We avoid from simultaneous procedure to prevent infected CSF flowing from lumbar region to ventricules. Also the longer operative procedure increases possibility of shunt infection. We believe that shunt placement should be carried out one week after the repair of MM sac. Ventricular tap may be performed according to severity of HCP until V-P shunt is inserted.

The high mortality rate in these patients shows importance of early closure of MM sac as soon as possible. Most of the infants dead were within the first month following surgery. In our study, gram negative organisms represented most of the pathogens. This shows that the MM sac is infected by neonatal intensive care unit or gaita, which emphasizes the importance early closure of the sac.

\section{CONCLUSION}

MM is obviously a cause of shunt infection. It is likely that the MM sac will be initially colonised and an infected MM sac might facilitate shunt infection. Therefore, we consider that V-P shunt placement should be performed in a separate session following MM sac repair after elimination of infection, especially in cases with perforated MM. We believe that simultaneous sac repair and shunt placement develop a greater risk for shunt infection. If possible, MM sac repair should be performed as soon as a child is born.

\section{REFERENCES}

1. Bell WO, Arbit E, Fraser RA: One-stage myelomeningocele closure and ventriculoperitoneal shunt placement. Surg Neurol 27:233-236, 1987

2. Brau RH, Rodriguez R, Ramirez MV, Gonzales R, Martinez V: Experience in the management of myelomeningocele in Puerto Rico. J Neurosurg 72:726-731, 1990

3. Caldarelli M, Di Rocco C, La Marca F: Shunt complications in the first postoperative year in chıldren with meningomyelocele. Child Nerv Syst 12:748-754, 1996

4. Chadduck WM, Reding DL: Experience with simultaneous ventriculo-peritoneal shunt placement and myelomeningocele repair. J Pediatr Surg 23: 913-916, 1988
5. Charney EB, Weller SC, Sutton LN, Bruce DA, Schut LB: Management of the newborn with myelomeningocele: Time for a decision making process. Pediatrics 75:58-64, 1985

6. Di Rocco C, Marchese E, Velardi F: A survey of the first complication of newly implanted CSF shunt devices for the treatment of non-tumoral hydrocephalus. Childs Nerv Syst 10:321- 327, 1994

7. Epstein NE, Rosenthal AD, Zito J, Osipoff M: Shunt placement and myelomeningocele repair: Simultaneous vs sequential shunting. Review of 12 cases. Childs Nerv Syst 1:145-147, 1985

8. Ersahin Y, Mutluer S, Guzelbag E: Cerebrospinal fluid shunt infections. J Neurosurg Sci 38: 161-165, 1994

9. Gamache FW Jr: Treatment of hydrocephalus in patients with meningomyelocele or encephalocele: A recent series. Childs Nerv Syst 11:487-488, 1995

10. Hubbalah MY, Hoffman HJ: Early repair of myelomeningocele and simultaneous insertion of ventriculoperitoneal shunt: Technique and results. Neurosurgery 20:21-23, 1987

11. Kaufman BA: Neural tube defect. Pediatr Clin North Am 51:389-419, 2004

12. Machado HR, Santos de Olivera R: Simultaneous repair of myelomeningocele and shunt insertion: Childs Nerv Syst 20:107-109, 2004

13. McAdams RM, Simone S, Grant G, DiGeronimo RJ: Ventricular peritoneal shunt infection resulting from group $B$ streptococcus. Pediatr Crit Care Med 7:586-588, 2006

14. McLone DG, Dias MS: Complications of myelomeningocele closure. Pediatr Neurosurg 17: 267-273, 1991

15. Miller PD, Pollack IF, Pang D, Albright AL: Comparison of simultaneous versus delayed ventriculoperitoneal shunt insertion in children undergoing myelomeningocele repair. J Child Neurol 11:370-372, 1996

16. Mirzai H, Ersahin Y, Mutluer S, Kayahan A: Outcome of patients with myelomengocele. Child's Nerve Syst 14:120-123, 1998

17. Netanyahu I, Grant EG: Prominent choroid plexus in meningomyelocele. Sonographic findings. AJNR 7:317-321, 1986

18. Oktem IS, Menku A, Ozdemir A: When should ventriculoperitoneal shunt placement be performed in cases with myelomeningocele and hydrocephalus? Turk Neurosurg 18:387-391, 2008

19. Parent AD, McMillan T: Contemporaneous shunting with repair of myelomeningocele. Pediatr Neurosurg 22:132-136, 1995

20. Radmanesh F, Nejat F, Khashab ME, Ghodsi SM, Ardebili HE: Shunt complications in children with myelomeningocele: Effect of timing of shunt placement. J Neurosurg Pediatrics 3: 516-520, 2009

21. Shurtleff DB, Kornmal R, Foltz EL: Follow up comparison of hydrocephalus with and without myelomeningocele. J Neurosurg 42:61-68, 1975

22. Smyth BT, Piggot J, Forsythe WI, Merret JD: A controlled trial of immediate and delayed closure of myelomeningocele. J Bone Joint Surg Br 56:294-304, 1974

23. Tuli S, Drake J, Lamberti-Pasculli M: Long - term outcome of hydrocephalus management in myelomeningocele. Childs Nerv Syst 19:286-291, 2003 